\title{
COMPARATIVE ANALYSIS OF LOCAL STIMULATION METHODS OF REPARATIVE OSTEOGENESIS
}

\author{
${ }^{1}$ Kuban State Medical University, Krasnodar, Russian Federation \\ ${ }^{2}$ Research Institute - Ochapovsky Regional Hospital no. 1, Krasnodar, Russian Federation \\ ${ }^{3}$ Moscow State University of Medicine and Dentistry, Moscow, Russian Federation \\ $\square$ * Mikhail L. Mukhanov, Kuban State Medical University, 4, M. Sedina str., Krasnodar, 350063, pputinn@yandex.ru \\ Received: October 31, 2021. Accepted: November 15, 2021.
}

Objective To determine the ratio of the main growth factors when using various methods of local stimulation of reparative osteogenesis.

Material and methods The study consisted of two parts: in the first part a comparative analysis of the content of growth factors by ELISA was carried out (PDGF - platelet derived growth factor, TGF - transforming growth factor, VEGF - vascular endothelial growth factor, IGF - insulin-like growth factor, BMP6 and BMP7 morphogenetic proteins 6 and 7), capable of stimulating reparative osteogenesis in blood plasma, plateletrich plasma, red bone marrow and bone autoregenerate.

The second part presented the results of approbation of the autoregenerate obtained according to the original method in the framework of an acute experiment on animals.

Results The most important cytokines affecting the process of reparative osteogenesis are fibroblast growth factor - FGF1 and bone morphogenetic protein 7 - BMP7. Based on the results of a comparative enzymelinked immunosorbent assay, it has been established that the autoregenerate, obtained by the original method, and a bone marrow aspirate concentrate have the highest osteogenic potential.

Conclusion Autoregenerate is an effective and promising means of local stimulation of reparative osteogenesis, and its transplantation is a simple and highly effective procedure.

Keywords:

Cite this article as: $\quad$ Mukhanov M.L., Blazhenko A.N., Bogdanov S.B., Sotnichenko A.S., Rusinova T.V., Verevkin A.A., Mukhanov M.L., Blazhenko A.N., Bogdanov S.B., Sotnichenko A.S., Rusinova T.V., Verevkin A.A.,
Aliev R.R., Zaremuk A.M., Porhanov V.A. Comparative analysis of local stimulation methods of reparative osteogenesis. Innovative Medicine of Kuban. 2021;(4):41-49. https://doi.org/10.35401/2500-0268-202124-4-41-49

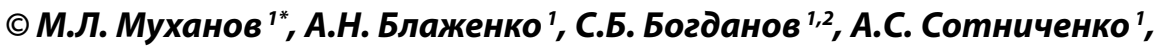 Т.В. Русинова' ', А.А. Веревкин ', Р.Р. Алиев ', А.М. Заремук ', В.А. Порханов 1 ', \\ СРАВНИТЕЛЬНЫЙ АНАЛИЗ МЕТОДИК ЛОКАЛЬНОЙ СТИМУЛЯЦИИ РЕПАРАТИВНОГО ОСТЕОГЕНЕЗА}

\author{
${ }^{1}$ Кубанский государственный медицинский университет, Краснодар, Россия \\ ${ }^{2}$ НИИ - Краевая клиническая больница № 1 им. проф. С.В. Очаповского, Краснодар, Россия \\ ${ }^{3}$ Московский государственный медико-стоматологический университет, Москва, Россия \\ $\triangle$ * М.Л. Муханов, 350063, Краснодар, ул. Седина, 4, pputinn@yandex.ru \\ Поступила в редакцию 31 октября 2021 г. Принята к печати 15 ноября 2021 г.
}

Цель

Материал и методы

Результаты
Определить соотношение основных факторов роста при применении различных методик локальной стимуляции репаративного остеогенеза.

Исследование состояло из двух частей: в первой проведен сравнительный анализ содержания факторов роста при помощи ИФА (PDGF - тромбоцитарный фактор роста, TGF - трансформирующий фактор роста, VEGF - фактор роста эндотелия сосудов, IGF - инсулиноподобный фактор роста, ВMP6 и ВMP7 - морфогенетические белки 6 и 7), способных стимулировать репаративный остеогенез в плазме крови, плазме, обогащенной тромбоцитами, красном костном мозге и костном ауторегенерате. Во второй части представлены результаты апробации ауторегенерата, полученного по оригинальной методике в рамках острого эксперимента на животных.

Наиболее важными цитокинами, влияющими на процесс репаративного остеогенеза, являются фактор роста фибробластов - FGF1 и костный морфогенетический белок 7 - ВМР7. Основываясь на результатах сравнительного иммуноферментного анализа, установлено, что наибольшими остеогенными потенциалами обладают ауторегенерат, полученный по оригинальной методике, и взвесь аспирата костного мозга. 
Заключение

Ключевые слова: Цитировать:
Ауторегенерат является эффективным и перспективным средством локальной стимуляции репаративного остеогенеза, а его трансплантация - простая и высокоэффективная процедура. регенерация, репаративный остеогенез, ауторегенерат, факторы роста Муханов М.Л., Блаженко А.Н., Богданов С.Б., Сотниченко А.С., Русинова Т.В., Веревкин А.А., Алиев Р.Р., Заремук А.М., Порханов В.А. Сравнительный анализ методик локальной стимуляции репаративного остеогенеза. Инновационная медицина Кубани. 2021;(4):41-49. https://doi. org/10.35401/2500-0268-2021-24-4-41-49

\section{INTRODUCTION}

In modern traumatology and orthopedics, disorders of the consolidation processes in bone fractures are a serious problem [1-4]. Many factors, both local and general $[1,5]$, lead to impairment of reparative osteogenesis [6-8]. Not only does this complicate the treatment of patients with fractures, but also increases the cost of the treatment. Therefore, the search for methods of local personalized impact on the zone of reparative osteogenesis for its stimulation is an important issue in modern medicine [9].

Nowadays, there are several treatment methods that can be used both independently and in combination to improve reparative osteogenesis. They include distal osteosynthesis [6, 7], as well as various methods of bone grafting, such as autologous bone grafts, allografts, and bone grafts substitutes $[8,9]$.

Despite the wide range of autologous bone grafts, their use is accompanied by various complications, such as chronic pain, nerves damage, arteries damage, and others, including possible infectious complications. In turn, synthetic transplant materials have a higher cost compared to autogenous material sources, and their properties are only limited by osteoconductive qualities. Combining the capabilities of autografts with synthetic materials seems to be promising [10].

Another technique, that has become increasingly widespread, is based on the principle of local stimulation of reparative osteogenesis using cytokines or growth factors $[2,3,12,13]$. These techniques include the use of platelet-rich plasma (PRP) [2], the introduction of a bone marrow aspirate concentrate (BMAC) into the fracture zone $[3,12,14]$, the use of synthetic growth factors such as bone morphogenetic proteins (BMPs) [3], fibroblast growth factor (FGF) [3], etc.

BMPs, among the other growth factors, are the most promising for stimulating reparative osteogenesis nowadays, since they have the most widely studied growth factors in the clinic. Despite this fact, BMPs' use, and indications for their use in trauma remain poorly studied. An important factor limiting their widespread use in the clinic is the high cost of the pure substance $[11,13]$.

All reparative osteogenesis stimulation methods, used in modern traumatology and orthopedics, give relatively satisfactory results. However, there are still drawbacks associated with both technical limitations in use (autograft from the iliac crest) and contradictory results of their use (PRP, BMPs). In addition, synthetic bone substitutes that have higher or even similar biological or mechanical properties compared to bone do not exist. Therefore, there is a need to develop new methods of treatment as an alternative or addition to existing methods $[2,3,14]$, considering a personalized approach to patient treatment.

\section{OBJECTIVE}

Determination of the main growth factors ratio using various methods of local stimulation of reparative osteogenesis.

All manipulations with animals were carried out in accordance with the guidelines for the treatment of laboratory animals accepted by the International Association of Veterinary Editors dated July 23, 2010, (European Convention for the Protection of Vertebrate Animals Used for Experimental and Other Scientific Purposes (ETS 123) Strasbourg, 1986), the study was approved by the independent ethical committee of the Kuban State Medical University of the Ministry of Health of Russia, Protocol no. 80 dated September 27, 2019.

\section{MATERIAL AND METHODS}

The first stage of the research: 2 rams of the 'Romanovskaya' breed, aged over 1 year, weighing $30.1 \pm 3.2 \mathrm{~kg}$.

The second stage of the research: 12 rams of the "Romanovskaya" breed, aged from 1 to 1.5 years with an average weight of $29.4 \pm 3.7 \mathrm{~kg}$, divided into two groups:

- control group (5) - fusion takes place on its own;

- study group (7) - stimulation of reparative osteogenesis using autoregenerate.

At the first stage of the research, a comparative analysis of agents for local stimulation of reparative osteogenesis, in particular red bone marrow, platelet-rich plasma and autoregenerate (obtained according to the original method) using enzyme-linked immunosorbent assay, was carried out, with the determination of titers of known growth factors.

To obtain red bone marrow a puncture of the ilium wing was performed with a collection of 15-20 ml of red bone marrow. Blood was also taken on the day of surgery to prepare platelet-rich plasma and native blood plasma. Venipuncture was performed with venous blood sampling $(15-20 \mathrm{ml})$.

The autoregenerate was obtained according to the original technique. Osteotomy of the iliac crest was per- 
formed as follows: after the access, an osteotomy was performed using a chisel and bone wounds were formed (fig. 1) up to $50.0 \mathrm{~mm}$ long, up to $10.0 \mathrm{~mm}$ wide and a depth of up to $30.0 \mathrm{~mm}\left(15000 \mathrm{~mm}^{3}=15.0 \mathrm{ml}\right)$, then within 5-7 days an autoregenerate was formed. It is an organizing clot (fig. 2), the liquid part of which was taken for enzyme immunoassay and morphological analysis, while the clot was taken for morphological research to quantitatively determine the cellular composition.

Immunological studies were carried out in the central research laboratory of the Kuban State University. Enzyme-linked immunosorbent assay (ELISA) was carried out for the concentration of the following cytokines: PDGFAB, TGFb1, BMP6, BMP7, IGF1, FGF1, by means of ELISA method using the following test systems (CloudClone Corp, USA): SEA436Ov ELISA Kit For Platelet Derived Growth Factor AB, SEA124Ov ELISA Kit For Transforming Growth Factor Beta 1, SEA646Ov ELISA Kit for Bone Morphogenetic Protein 6, SEA799Ov ELISA Kit for Bone Morphogenetic Protein 7, SEA050Ov ELISA Kit for Insulin Like Growth Factor 1, SEA032Ov ELISA Kit for Fibroblast Growth Factor Acidic, in accordance with the manufacturer's protocol on a FilterMax F5 microplate reader (USA).

Immunohistochemical analysis was performed using the following kits:

- DF12303 Osteocalcin Antibody, $100 \mu \mathrm{L}$

- DF6395 SPP1 Antibody, $100 \mu \mathrm{L}$

- AF0564 MRC2 Antibody, $100 \mu \mathrm{L}$

- AF5193 BMP7 Antibody, $100 \mu \mathrm{L}$

At the second stage, within the framework of an acute experiment, the effect of transplanted bone autoregenerate on reparative osteogenesis during fracture consolidation was studied. Restoration of a bone defect, artificially created during surgical intervention, was also studied during the experiment.

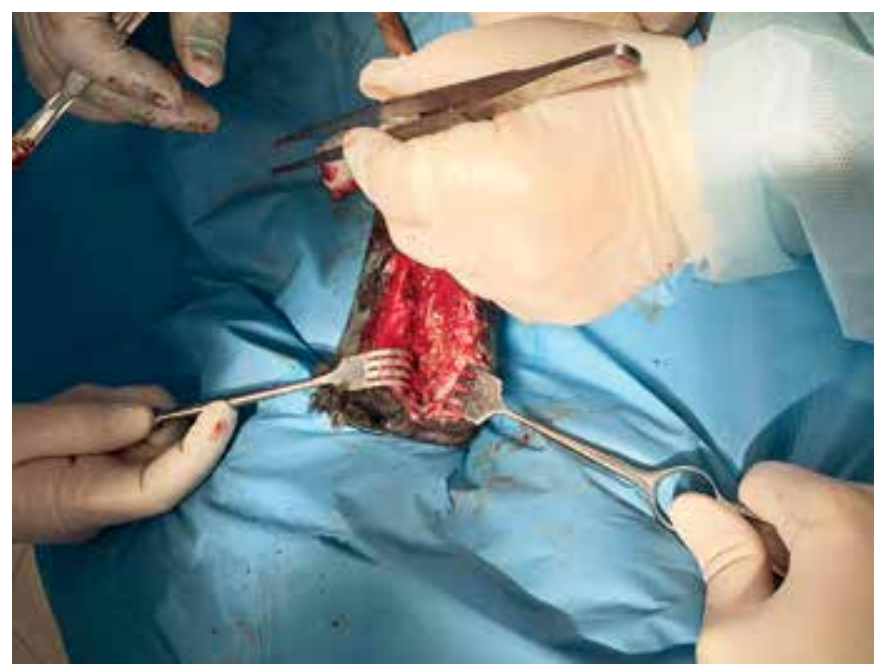

Figure 1. Ilium wing osteotomy

Рисунок 1. Остеотомия крыла подвздошной кости

\section{RESULTS OF THE FIRST STAGE OF THE RESEARCH}

A comparative analysis of the growth factors content was carried out for the first time using ELISA (PDGF - platelet derived growth factor, TGF - transforming growth factor, VEGF - vascular endothelial growth factor, IGF - insulin-like growth factor, BMP6 and BMP7 - morphogenetic proteins 6 and 7), capable of stimulating reparative osteogenesis in blood plasma, platelet-rich plasma, red bone marrow and bone autoregenerate. The results are presented graphically in the figure (fig. 3).

As a result of the comparative analysis, it was possible to find out that such cytokines as fibroblast growth factor - FGF1, bone morphogenetic protein 7 - BMP7, to a lesser extent insulin-like growth factor - IGF1, transforming growth factor beta - TGFb, and bone morphogenetic protein 6 - BMP6 prevail in the autoregeneration process, as well as the number of growth factors required for reparative regeneration processes. Platelet-rich plasma contains a large amount of platelet derived growth factor - PDGF.

Thus, the optimal ratio of the main cytokines required to optimize the processes of reparative osteogenesis has been identified. The data are presented in the diagram (fig. 3).

When it comes to content of growth factors the closest to the autoregenerate, which is a hematoma from the area of the consolidating fracture, is a suspension of red bone marrow, while in blood plasma and platelet-rich plasma growth factors concentration was significantly lower.

Thus, as a result of the first part of the research, it was established that the autoregenerate, obtained according to the original technique, differs from the suspension of bone marrow aspirate concentrate (BMAC) as well as from the platelet-rich blood plasma (PRP), which are the most widespread methods of local stimulation of reparative osteogenesis.

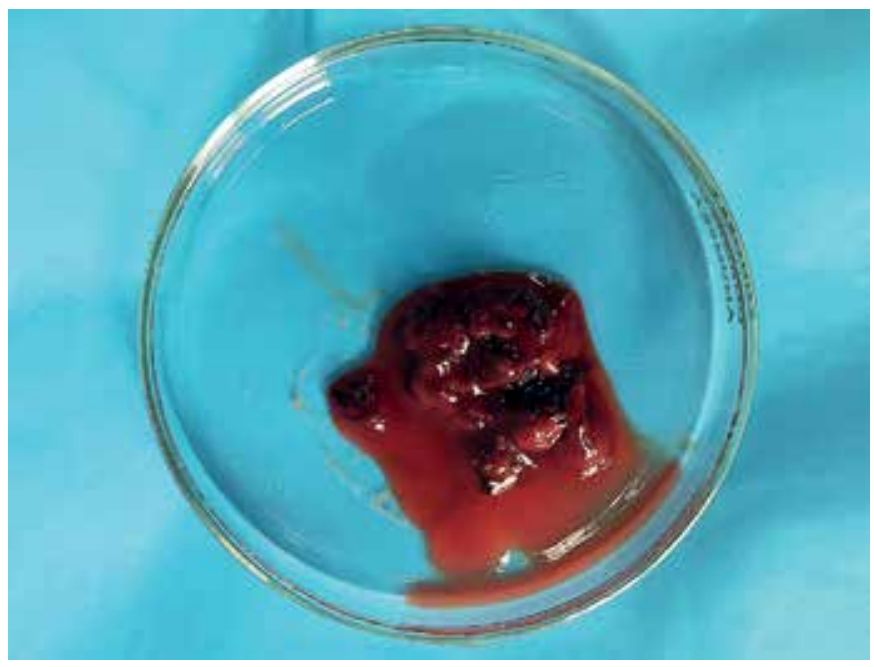

Figure 2. Autoregenerate obtained from the wing of the ilium Рисунок 2. Ауторегенерат, полученный из крыла подвздошной кости 

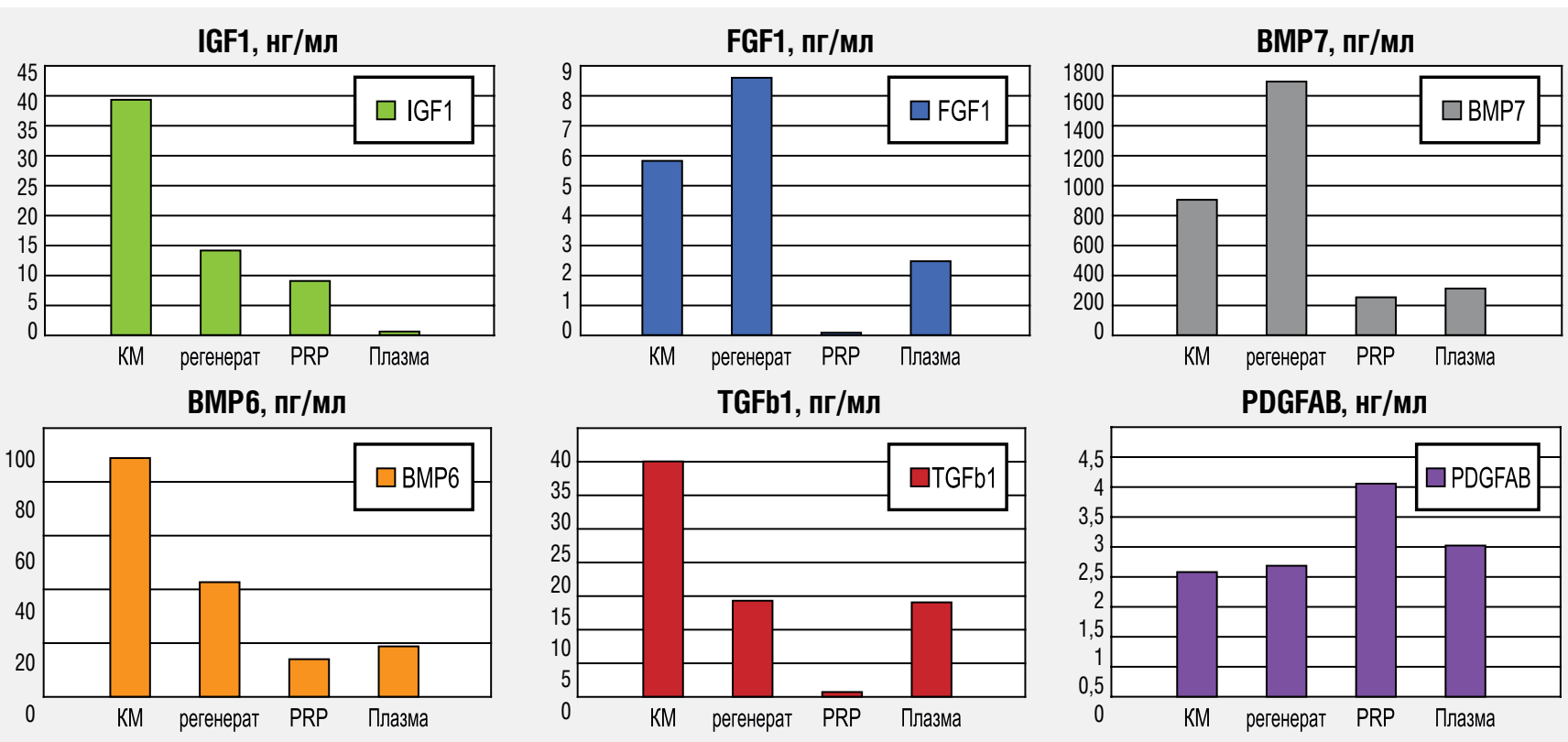

Figure 3. Comparative analysis of cytokine content in red bone marrow (BMAC), bone autoregenerate, platelet-rich plasma (PRP) and blood plasma

Рисунок 3. Сравнительный анализ содержания ичитокинов в красном костном мозге (ВМАС), костном ауторегенерате, плазме, обогащенной тромбоцитами (PRP) и плазме крови

\section{SECOND STAGE OF THE RESEARCH}

Based on the results of the first part of the research, an acute experiment was carried out, where, according to the results of a comparative analysis, on the basis of clinical, radiological, histological and immunohistological data, the impact of autoregenerate transplantation on reparative osteogenesis was established.

The animals of the study group underwent osteotomy of the iliac crest performed according to the original technique. Then, on the $5^{\text {th }}$ day after osteotomy of the iliac crest, a tibial fracture model with a wedge-shaped defect, preventing the normal fracture fusion, was created. Fragment fixation was performed using the bone osteosynthesis technology, using a dynamic compression plate of limited contact (LCDCP), the plate was fixed with cortical screws (fig. 4, 5).

Animals from the control group underwent a similar fracture model, but the treatment was carried out without additional local stimulation of reparative osteogenesis by any methods.

Autoregenerate bone was transplanted to all animals of the study group at the time of the tibial fracture model formation (fig. 6).

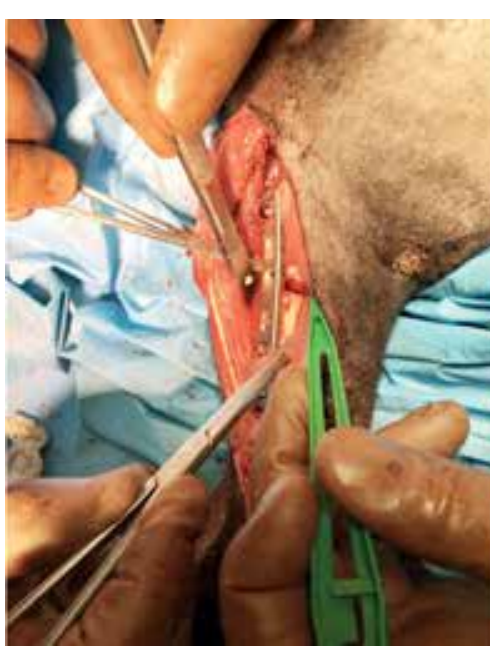

Figure 4. Tibial fracture model, bone osteosynthesis was performed Рисунок 4. Модель перелома большеберцовой кости, выполнен накостный остеосинтез

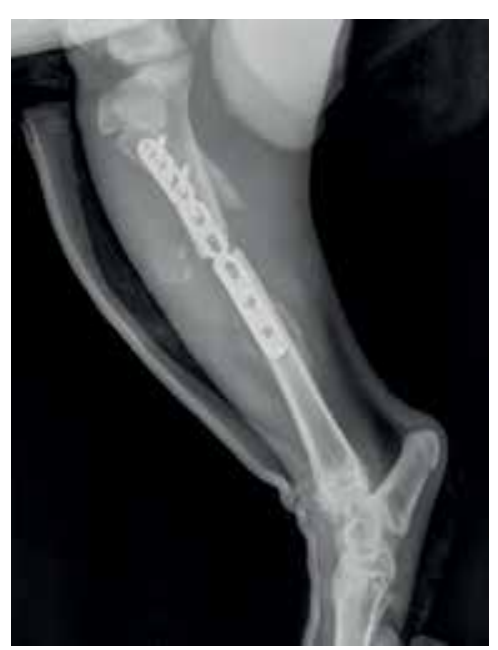

Figure 5. X-ray control in the early postoperative period

Рисунок 5. Рентгенологический контроль в раннем послеоперационном периоде

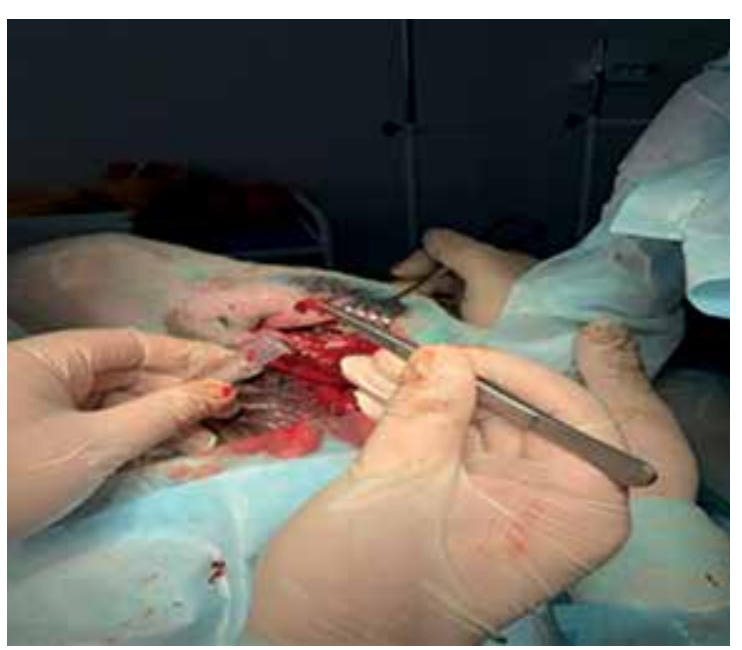

Figure 6. Autoregenerate transplantation Рисунок 6. Трансплантация ауторегенерата 

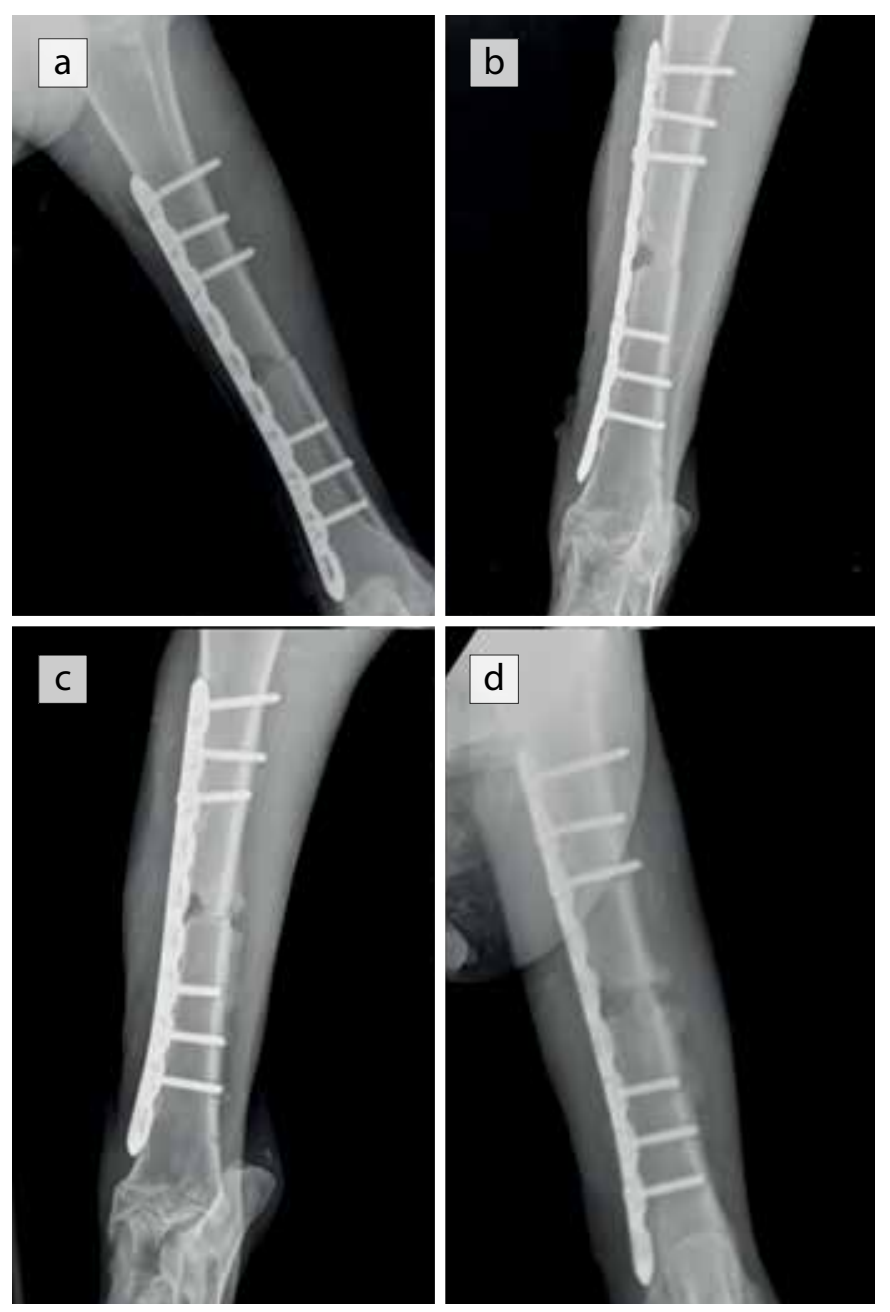

Figure 7. Control radiographs of the animals from the study group (timing is described in the text)

Рисунок 7. Контрольные рентгенограммы животного исследуемой группы (сроки выполнения описаны в тексте)

On the control radiographs of animals of the study group, performed on the day of surgery (fig. 7a), on the $7^{\text {th }}$ day (fig. 7b), $14^{\text {th }}$ day (fig. $7 \mathrm{c}$ ) and $21^{\text {st }}$ day after the surgery (fig. 7d), signs of fracture fusion and gradual filling of the wedge-shaped bone defect can be seen (fig. 7c, d).

On a series of radiographs of animals from the control group, the absence of local stimulation of reparative osteogenesis led to the expected impairment of fracture consolidation. Control radiographs were performed on the day of surgery (fig. 8a), on the $7^{\text {th }}$ day (fig. 8b), $14^{\text {th }}$ day (fig. 8c) and $21^{\text {st }}$ day (fig. 8d).

On the 21 st day of the second part of the research, some of the animals were removed from the experiment by means of euthanasia for autopsy, histological and immunohistochemical studies.

In animals of the study group the autopsy showed complete consolidation of the fracture, as well as filling of the wedge-shaped defect with bone tissue in the fracture model area. In addition, the bone tissue filled the medullary canal cavity and the space under the plate (fig. 9), therefore, the autoregenerate began to penetrate
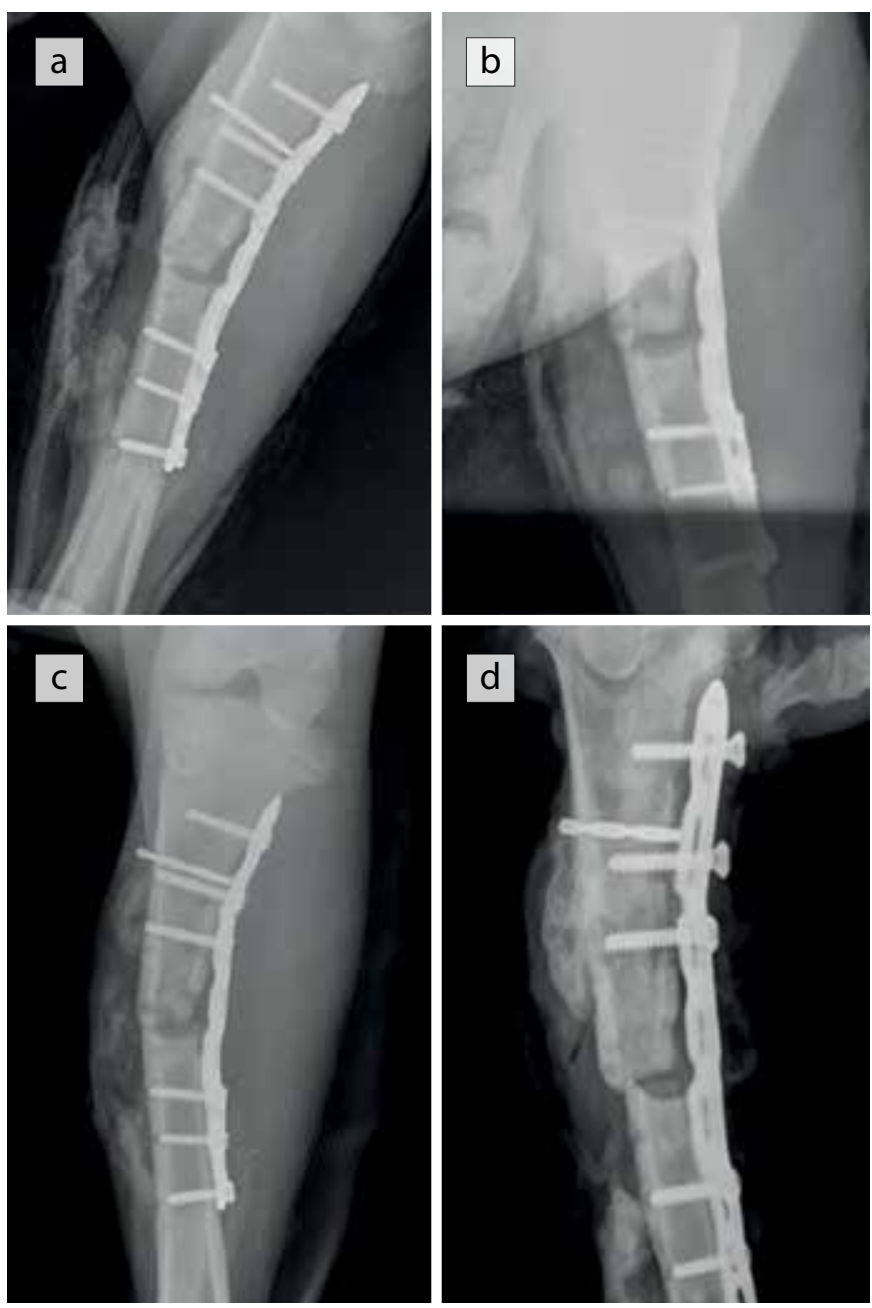

Figure 8. Control radiographs of the animals from the control group (timing is described in the text)

Рисунок 8. Контрольные рентгенограммы - животное контрольной группы (сроки выполнения описаны в тексте)

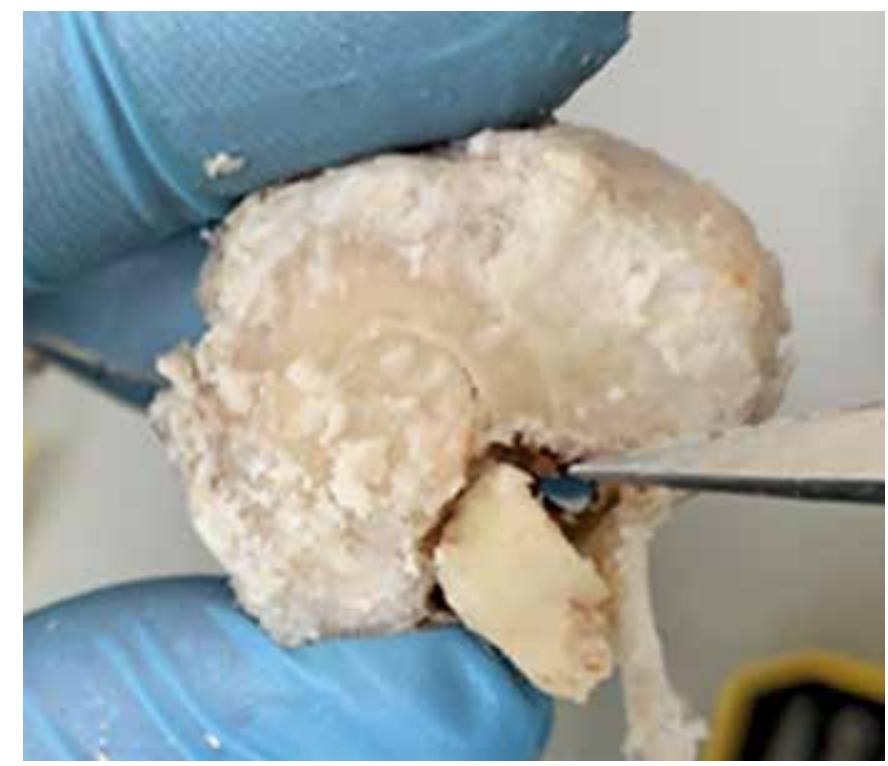

Figure 9. Tibia fragment on the $21^{\text {st }}$ day after autoregenerate transplantation

Рисунок 9. Участок большебериовой кости на 21-е сутки после трансплантации ауторегенерата 


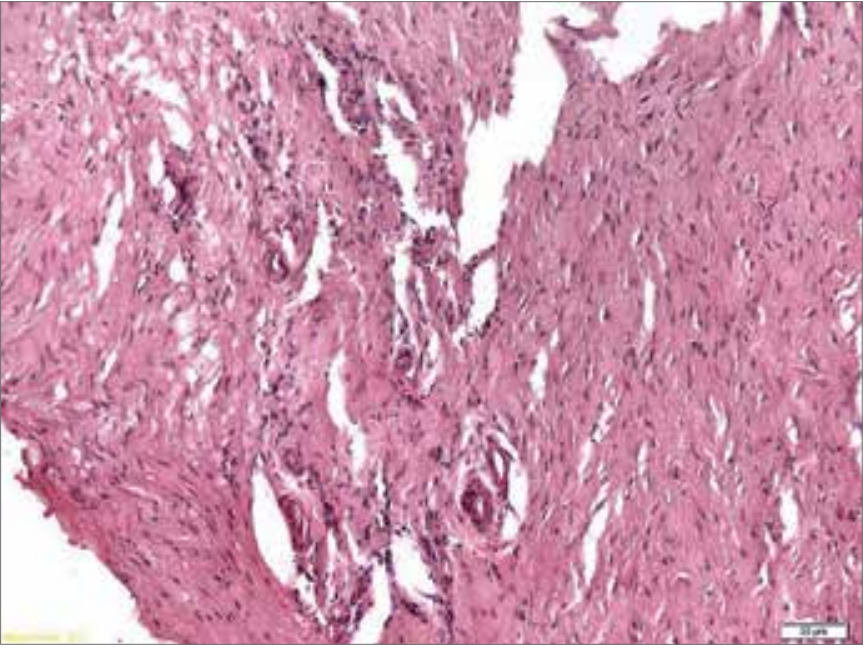

Figure 10. Histological examination. Tibia fragment on the $21^{\text {st }}$ day after autoregenerate transplantation

Рисунок 10. Гистологическое исследование. Участок большебериовой кости на 21-е сутки после трансплантации ауторегенеpama

into the bone tissue, which was histologically confirmed (fig. 10).

In the control group, signs of fracture fusion were noted only at the place of contact of bone fragments. No filling of the wedge-shaped defect in the area of the fracture model was revealed. During the histological analysis of callus, the impact of autoregenerate transplantation on the optimization of the reparative osteogenesis process was established. A histological specimen shows a greater number of bone tissue precursor cells, forming blood vessels, connective tissue fibers have an ordered structure (fig. 10). At the same time, on a specimen obtained from

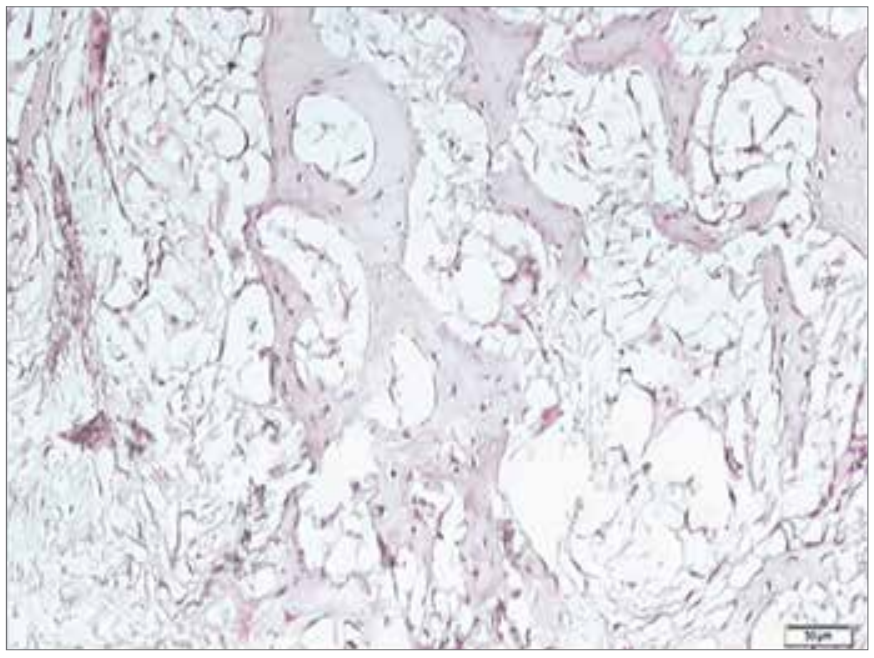

Figure 12. Bone tissue regeneration in an experimental animal. Large trabeculae with numerous lacunae, pronounced cellular component. Hematoxylin and eosin. Magnification: $\times 20$

Рисунок 12. Регенерация костной ткани у экспериментального животного. Крупные трабекулы с многочисленными лакунами, выраженный клеточный компонент. Гематоксилин-эозин. Увеличение: $\times 20$

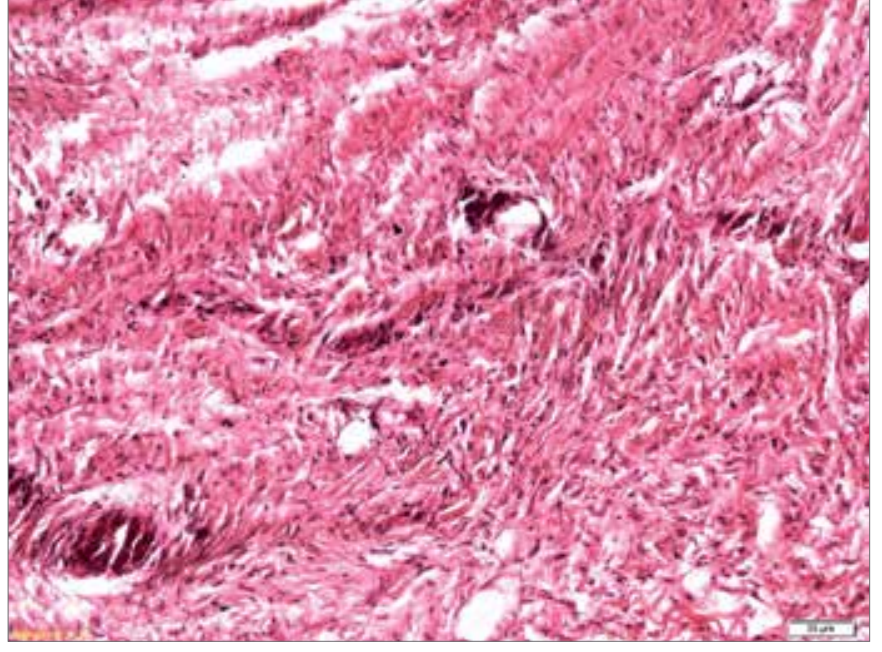

Figure 11. Histological examination. Tibia fragment on the $21^{\text {st }}$ day after osteosynthesis, without stimulation of osteogenesis

Рисунок 11. Гистологическое исследование. Участок большеберцовой кости на 21-е сутки после остеосинтеза, без стимуляции остеогенеза

an animal that did not undergo autoregenerate transplantation, such signs of bone tissue formation were found in a much smaller amount (fig. 11).

During the immunohistochemical analysis, active osteogenesis was revealed in the sample from the area of fracture healing in the experimental animal. The presence of a large number of lacunae with a pronounced cellular component (fig. 12). The microvasculature of the newly formed bone is represented by a large number of thin-walled capillaries, which give a positive reaction to the platelet-endothelial cell adhesion molecule CD31 (fig. 13).

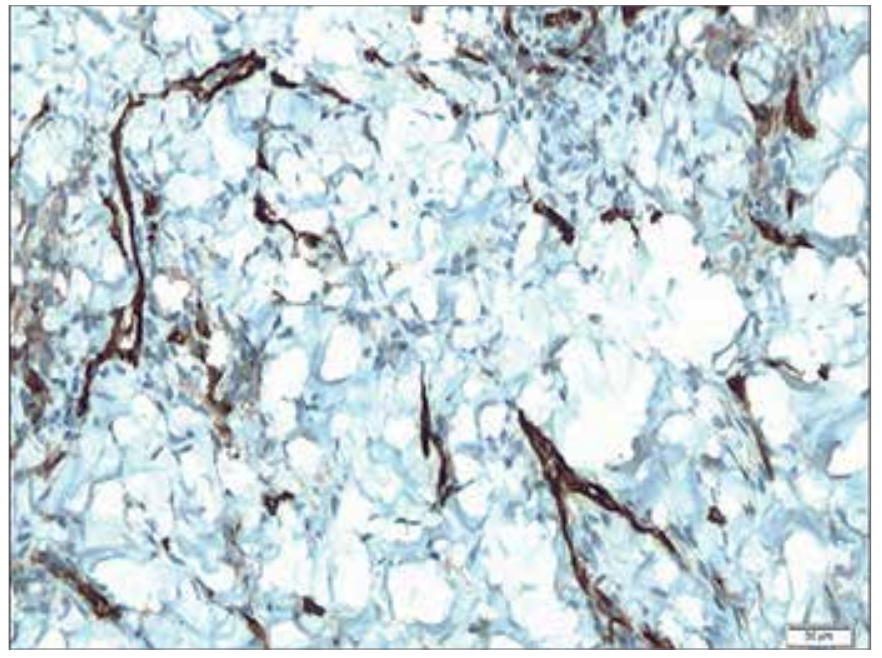

Figure 13. Capillaries of newly formed bone tissue that are positive for CD31. Streptavidin-peroxidase immunohistochemical reaction. Magnification: $\times 20$

Рисунок 13. Капилляры новообразованной костной ткани, дающие положительную реакиию на CD31. Стрептавидин-пероксидазная иммуногистохимическая реакция. Увеличение: $\times 20$ 


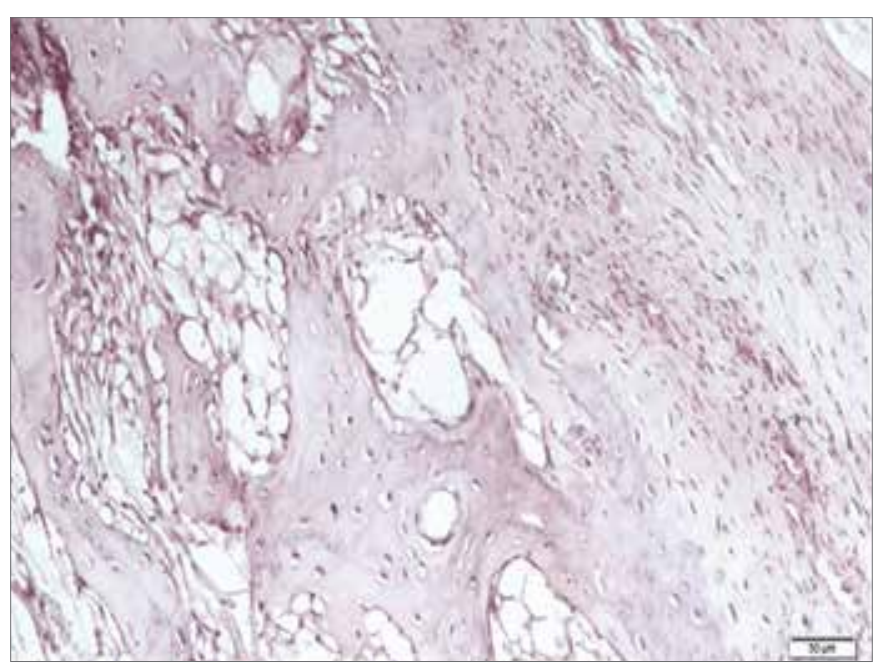

Figure 14. Bone regeneration in a control animal. Foci of adipose tissue development, cartilaginous metaplasia. Severe mononuclear infiltration. Hematoxylin and eosin. Magnification: $\times 20$

Рисунок 14. Регенерация костной ткани у контрольного животного. Очаги развития жировой ткани, хрящевая метаплазия. Выраженная мононуклеарная инфильтрация. Гематоксилин-эозин. Увеличение: $\times 20$

An immunohistochemical study with antibodies to osteocalcin and osteopontin revealed a diffuse arrangement of cells differentiating in the osteogenic direction. Immunophenotyping of macrophages, positive according to the type II mannose receptor (MRC-2) revealed few cells around the bone trabeculae, which indicates a weak resorption of the newly formed bone. In animals from the control group, where no stimulation of reparative osteogenesis was observed, there was a pronounced fibrocartilaginous metaplasia in the area of the defect (fig. 14).

The trabeculae of the newly formed bone were significantly thinner, the cellular component was less pronounced. Immunophenotyping of the cellular elements of the regeneration zone revealed a moderate number of osteocalcin-positive cells and a low number of osteopontin-positive cells. A significant number of MRC2-positive cells was also revealed, represented by macrophages in the connective tissue and osteoclasts in the newly formed bone (fig. 15). This shows moderate inflammation with concomitant bone tissue resorption.

Thus, based on the results of the research, precisely on the data of enzyme immunoassay, histological and immunohistochemical analysis, as well as clinical, radiological findings and autopsy data, it was possible to establish that the use of autoregenerate contains an optimal ratio of cytokines to stimulate reparative osteogenesis. Its transplantation is effective and promising in terms of bone formation processes stimulation. It is necessary to study it further on experimental models (animals) and assess the possibilities of practical application of the results obtained.

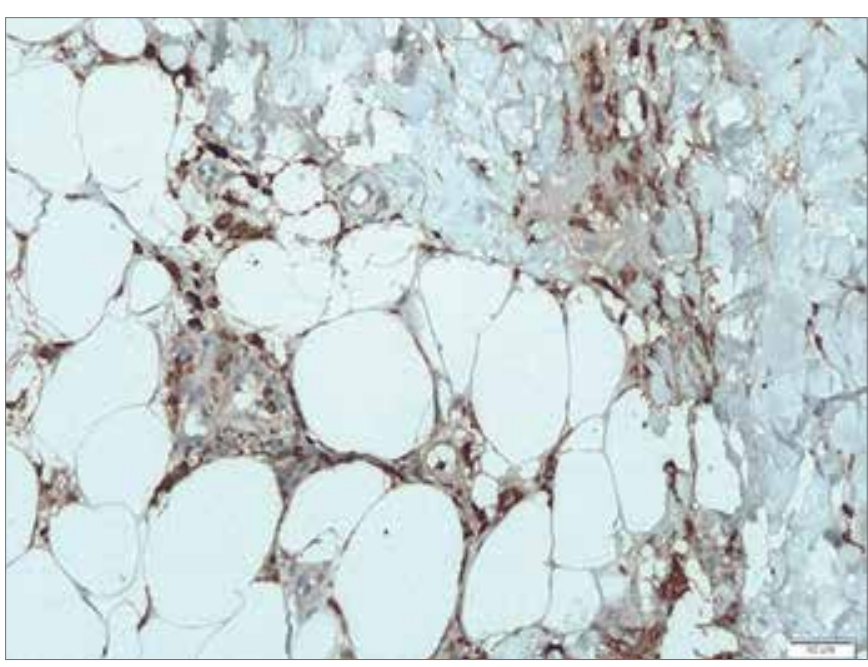

Figure 15. Significant accumulation of MRC2-positive cells in the regenerating bone tissue. Streptavidin-peroxidase immunohistochemical reaction. Magnification: $\times 20$

Рисунок 15. Значительное скопление MRC2-позитивных клеток в регенерирующей костной ткани. Стрептавидин-пероксидазная иммуногистохимическая реакция. Увеличение: $\times 20$

\section{CONCLUSION}

Despite the achievements of modern traumatology and orthopedics in improving the methods of surgical treatment of bone fractures, such as the use of plates with limited contact, screws with angular stability, and the use of modern bioinert materials, there are still such complications of osteosynthesis as delayed consolidation and, as a result, false joints formation.

Thus, the relevance of studying the already known mechanisms of action factors of local reparative osteogenesis stimulation and searching for the new ones is currently very high [3]. Many questions remain unresolved and there is a need for further study of the possibilities of using combinations of cytokines both independently and together with osteoconductive material [15].

According to the data presented in our research (fig. 3), platelet-rich plasma has a stimulating effect on reparative osteogenesis, but for several reasons does not have pronounced osteoinductive properties. The effect can be explained by the natural ability of platelets to influence healing processes by stimulating the regenerative potential of bone. tissue due to non-specific growth factors.

The greatest potential in stimulating reparative osteogenesis was shown by red bone marrow and autoregenerate obtained according to the original method. Based on the data of enzyme-linked immunosorbent assay, the qualitative and quantitative growth factors indicators, necessary to optimize the processes of reparative osteogenesis, were determined. The autoregenerate, obtained and tested during the experiment, showed its potential in the local stimulation processes of reparative osteogenesis during an acute experiment. 
Thus, the use of autoregenerate in order to optimize the processes of reparative osteogenesis can be considered one of the safest methods of local stimulation of osteogenesis processes. The possibility of using this technology in clinical medicine requires further research aimed at creating protocols for performing the procedure.

\section{RESULTS}

1. The most important cytokines affecting the process of reparative osteogenesis are fibroblast growth factor - FGF1 and bone morphogenetic protein 7 - BMP7.

2. Autoregenerate is an effective and promising means of local stimulation of reparative osteogenesis, and its transplantation is a simple and highly effective procedure.

3. Based on the results of a comparative enzyme-linked immunosorbent assay, it has been established that the autoregenerate, obtained by the original method, and a bone marrow aspirate concentrate have the highest osteogenic potential.

\section{REFERENCES/ЛИТЕРАТУPA}

1. Alekseenko SN, Redko AN, Karipidi RK, Zakharchenko YuI. Primary disability of the adult population of the Krasnodar region due to road traffic accidents. Bulletin of the All-Russian Society of Specialists 44 on Medical and Social Expertise, Rehabilitation and Rehabilitation Industry. 2017;4:44-48. (In Russ.)

Алексеенко С.Н., Редько А.Н., Карипиди Р.К., Захарченко Ю.И. Первичная инвалидность взрослого населения краснодарского края вследствие дорожно-транспортных происшествий. Вестник Всероссийского общества специалистов 44 по медико-социальной экспертизе, реабилитации и реабилитациионной индустрии. 2017;4:44-48.

2. Blazhenko AN, Rodin IA, Ponkina ON, et al. The effect of A-PRP-therapy on reparative regeneration of bone tissue with acute bone fractures of the limbs. Innovative Medicine of Kuban. 2019;(3):32-38. https://doi.org/10.35401/2500-0268-2019-15-332-38 (In Russ.)

Блаженко А.Н., Родин И.А., Понкина О.Н., и др. Влияние A-PRP-терапии на репаративную регенерацию костной ткани при свежих переломах костей конечностей. Инновационная медичина Кубани. 2019;(3):32-38. https://doi.org/10.35401/25000268-2019-15-3-32-38

3. Sadykov RI, Akhtyamov IF. Local factors of stimulations of reparative osteogenesis (literature review). Department of Traumatology and Orthopedics. 2020;(3):23-30. http://doi. org/10.17238/issn2226-2016.2020.3.23-30 (In Russ.)

Садыков Р.И., Ахтямов И.Ф. Локальные факторы стимуляции репаративного остеогенез (обзор литературы). Кафедра травматологии и ортопедии. 2020;(3):23-30. http:// doi.org/10.17238/issn2226-2016.2020.3.23-30

4. Miromanov AM, Gusev KA, Uskov SA, Davydov SO, Miromanova NA. Current approaches to diagnosis of fracture consolidation disorders. Genij Ortopedii. 2017;23(1):12-15. http:// doi.org/10.18019/1028-4427-2017-23-1-12-15 (In Russ.)

Мироманов А.М., Гусев К.А., Усков С.А., Давыдов С.О., Мироманова Н.А. Современные подходы к диагностике нарушений консолидации при переломах. Гений ортопедии. 2017;23(1):12-15. http://doi.org/10.18019/1028-4427-2017-23-1$12-15$
5. Shastov AL. Management of posttraumatic long bone defects in the national orthopedic practice (literature review). Genij Ortopedii. 2018;24(2):252-257. http://doi.org/10.18019/10284427-2018-24-2-252-257 (In Russ.)

Шастов А.Л. Проблема замещения посттравматических дефектов длинных костей в отечественной травматолого-ортопедической практике (обзор литературы). Гений ортопедии. 2018;24(2):252-257. http://doi.org/10.18019/1028-4427-2018-242-252-257

6. Aronson J. Limb-lengthening, skeletal reconstruction, and bone transport with the Ilizarov method. J Bone Joint Surg Am. 1997;79(8):1243-1258. http://doi.org/10.2106/00004623199708000-00019

7. Green SA, Jackson JM, Wall DM, Marinow H, Ishkanian J. Management of segmental defects by the Ilizarov intercalary bone transport method. Clin Orthop Relat Re. 1992;28:136-142. PMID: 1611733.

8. Giannoudis PV, Dinopoulos H, Tsiridis E. Bone substitutes: an update. Injury. 2005;36(3):20-27. http://doi.org/10.1016/j. injury.2005.07.029

9. Giannoudis PV, Einhorn TA. Bone morphogenetic proteins in musculoskeletal medicine. Injury. 2009;40(3):1-3. http:// doi.org/10.1016/S0020-1383(09)00642-1

10. St John TA, et al. Physical and monetary costs associated with autogenous bone graft harvesting. American journal of orthopedics (Belle Mead NJ). 2003;32(1):18-23. PMID: 12580346.

11. Nauth A, et al. Growth factors: beyond bone morphogenetic proteins. Journal of orthopaedic trauma. 2010;24(9):543546. http://doi.org/10.1097/BOT.0b013e3181ec4833

12. Salgado AJ, Coutinho OP, Reis RL. Bone tissue engineering: state of the art and future trends. Macromol Biosci. 2004;4(8):743-765. http://doi.org/10.1002/mabi.200400026

13. Rose FR, Oreffo RO. Bone tissue engineering: hope vs hype. Biochem Biophys Res Commun. 2002;292:1-7. http://doi. org/10.1006/bbrc.2002.6519

14. Korzh NA, Vorontsov PM, Vishnyakova IV, Samoilova EM. Innovative methods for optimization of bone regeneration: mesenchymal bone cells (part 2) (literature review). Orthopedics, traumatology and prosthetics. 2018;1:105-116. http://dx.doi. org/10.15674/0030-598720181105-116 (In Russ.)

Корж Н.А., Воронцов П.М., Вишнякова И.В., Самойлова Е.М. Инновационные методы оптимизации регенерации кости: мезенхимальные стволовые клетки (сообщение 2) (обзор литературы). Ортопедия, травматология и протезирование. 2018;1:105-116. http://dx.doi.org/10.15674/0030-598720181105116

15. Talashova IA, Osipova EV, Kononovich NA. Comparative quantitive evaluation of reparative process for implantation of biocompositional materials into bone defects. Genij Ortopedii. 2012;2:68.

Талашова И.А., Осипова Е.В., Кононович Н.А. Сравнительная количественная оценка репаративного процесса при имплантации биокомпозиционных материалов в костные дефекты. Гений ортопедии. 2012;2:68.

\section{AUTHOR CREDENTIALS}

Mikhail L. Mukhanov, Cand. of Sci. (Med.), Associate Professor of the Department of orthopedics, traumatology and military surgery, Kuban State Medical University (Krasnodar, Russian Federation). https://orcid.org/0000-0002-9061-6014

Alexander N. Blazhenko, Dr. of Sci. (Med.), Professor of the Department of orthopedics, traumatology and military surgery, Kuban State Medical University (Krasnodar, Russian Federation). https://orcid.org/0000-0002-9957-1422 
Sergey B. Bogdanov, Dr. of Sci. (Med.), Professor of the Department of orthopedics, traumatology and military surgery, Kuban State Medical University, Head of the Burns Center, Research Institute - Ochapovsky Regional Hospital no. 1 (Krasnodar, Russian Federation). https://orcid.org/0000-0001-9573-4776

Alexander S. Sotnichenko, Associate Professor of the Department of pathological anatomy, Kuban State Medical University (Krasnodar, Russian Federation). https://orcid.org/0000-00017322-0459

Tatiana V. Rusinova, Cand. of Sci. (Bio.), Research fellow at the central research laboratory, Kuban State Medical University (Krasnodar, Russian Federation). https://orcid.org/0000-00032962-3212

Alexander A. Verevkin, assistant of the Department of pathological anatomy, Kuban State Medical University (Krasnodar, Russian Federation). https://orcid.org/0000-0002-4159-2618

Ramzan R. Aliev, clinical resident, Department of surgery no. 1, Kuban State Medical University (Krasnodar, Russian Federation). https://orcid.org/0000-0002-9885-6223

Adam M. Zaremuk, Cand. of Sci. (Med.), Associate Professor of the Endoscopic Surgery Department, Postgraduate Education Faculty, Moscow State Medical and Dental University, (Moscow, Russian Federation). https://orcid.org/0000-0002-66309735

Vladimir A. Porhanov, Academician of the Russian Academy of Sciences, Dr. of Sci. (Med.), Professor, Chief Doctor of Research Institute - Ochapovsky Regional 1 Hospital no. 1; Head of the Department of Oncology with the Course of Thoracic Surgery, Faculty of Advanced Training and Professional Retraining of Specialists, Kuban State Medical University (Krasnodar, Russian Federation). https://orcid.org/0000-0003-0572-1395

Funding: The study was carried out with the financial support of the Russian Foundation for Basic Research within the framework of the scientific project no. 19-415-233004/19(20) "r_mol_a" dated April 22, 2019.

Conflict of interest: none declared.

\section{СВЕДЕНИЯ ОБ АВТОРАХ}

Муханов Михаил Львович, к. м. н., доцент кафедры ортопедии, травматологии и ВПХ, Кубанский государственный медицинский университет (Краснодар, Россия). https://orcid. org/0000-0002-9061-6014
Блаженко Александр Николаевич, д. м. н., профессор кафедры ортопедии, травматологии и ВПХ, Кубанский государственный медицинский университет (Краснодар, Россия). https://orcid.org/0000-0002-9957-1422

Богданов Сергей Борисович, д. м. н., профессор кафедры ортопедии, травматологии и ВПХ, Кубанский государственный медицинский университет; заведующий ожоговым центром, НИИ - ККБ № 1 им. проф. С.В. Очаповского (Краснодар, Россия). https://orcid.org/0000-0001-9573-4776

Сотниченко Александр Сергеевич, доцент кафедры патологической анатомии ФПК и ППС, Кубанский государственный медицинский университет (Краснодар, Россия). https:// orcid.org/0000-0001-7322-0459

Русинова Татьяна Викторовна, к. б. н., научный сотрудник центральной научно-исследовательской лаборатории, Кубанский государственный медицинский университет (Краснодар, Россия). https://orcid.org/0000-0003-2962-3212

Веревкин Александр Александрович, ассистент кафедры патологической анатомии ФПК и ППС, Кубанский государственный медицинский университет (Краснодар, Россия). https://orcid.org/0000-0002-4159-2618

Алиев Рамзан Русланович, ординатор кафедры хирургии № 1 ФПК и ППС, Кубанский государственный медицинский университет (Краснодар, Россия). https://orcid.org/0000-00029885-6223

Заремук Адам Муратчериевич, к. м. н., доцент кафедры эндоскопической хирургии факультета последипломного образования, Московский государственный медико-стоматологический университет (Москва, Россия). https://orcid.org/00000002-6630-9735

Порханов Владимир Алексеевич, академик РАН, д. м. н., профессор, главный врач, НИИ - ККБ № 1 им. проф. С.В. Очаповского; заведующий кафедрой онкологии с курсом торакальной хирургии ФПК и ППС, Кубанский государственный медицинский университет (Краснодар, Россия). https://orcid.org/0000-0003-0572-1395

Финансирование Исследование выполнено при финансовой поддержке РФФИ в рамках научного проекта № 19-415-233004/19(20) «p_мол_а» от 22.04.2019 г.

Конфликт интересов

Авторы заявляют об отсутствии конфликта интересов. 